\title{
CORPORATE SOCIAL RESPONSIBILITY OF ISLAMIC BANK'S PRACTICES: AN EXPLORATORY STUDY
}

\author{
Wan Noor Hazlina Wan Jusoh ${ }^{1 *}$, Uzaimah Ibrahim²*
}

\begin{tabular}{l}
\hline * Affiliation: \\
${ }^{1}$ Academy of \\
Contemporary Islamic \\
Studies, Universiti \\
Teknologi MARA \\
Terengganu Branch, \\
Dungun Campus, 23000 \\
Dungun, Terengganu, \\
Malaysia. wanno561@, \\
tganu.uitm.edu.my \\
22Ahmad Ibrahim \\
Kulliyyah of Law, \\
International Islamic \\
University Malaysia.
\end{tabular}

Abstract:

The purpose of this paper is to explore the corporate social responsibility (CSR) practices of an Islamic bank, which is Bank Islam Malaysia Berhad (BIMB). This research used face-to-face interview technique as a research method in order to get data that are more accurate. The data analysis focuses on four CSR themes namely, zakat, charitable activities, employee and environment. The findings show that BIMB has applied CSR practices in various ways and does not merely focussing on zakat and charitable activities as debated in previous studies in other Islamic banks. This paper contributes to the growing debate on CSR among Islamic financial institutions especially in Islamic banking industry by exploring new visibilities.

Keywords: Corporate social responsibility, Islamic bank, Bank Islam Malaysia Berhad, semi-structured interview

\section{INTRODUCTION}

Corporate social responsibility (CSR) has become an area of intense that attracting both practitioners and academicians (see Hassan \& Harahap, 2010; Jamali \& Karam, 2016). Even, the studies on CSR have grown exponentially at present by looking at more and more companies are engaged in serious efforts to define and incorporate CSR into all aspects of their business due to its positive impact on business economic performance (Mohammed, 2007) and the demands by stakeholders that the organizations should behave responsibly in the conduct of their economic business activities (Darus, Yusoff, Zain, \& Amran, 2016). The concern over CSR is also significant to Islamic banks. As a business entity established within the scope of Islamic law (Shari'ah), Islamic banks are expected to be guided by an Islamic worldview, which is based on principle of social justice and wellbeing (Dusuki, 2006). This is particularly true since those involved in Islamic banking and finance normally regard their ethics and social responsibility commitment as being more enduring since they are ultimately based on divine revelation, whereas ethics and social responsibility derived from secularist morality are unavoidably temporary (Wilson, 2001). 
CSR does not mean just participating in charitable activities and events; it denotes holding the responsibility to build up the society by envisioning future plans for socio-economic justice and be cognisant about their responsibility for the welfare of society around them (Masruki, Ibrahim, \& Azizan, 2010). Islamic banks are not excluded from this responsibility. In fact, their CSR expectation is more compared to conventional banks (Dusuki, 2006) since they are in exemplary position in society as financial intermediaries (Farook, 2007). The Islamic banks as part of business community are highly qualified to set plans for social change, and integrate their development goals with the country's agenda at large, as well as engage with the other organisations on collaborative projects.

Although Islamic banks pay zakat, giving sadaqa (Khir, Gupta, \& Shanmugam, 2008), avoiding riba (interest) and gharar (uncertainty) in banking activities (Farook, 2007; Mohammed, 2007) which are considered as among the most indicators of CSR of Islamic banks, stakeholders of Islamic banks are least concerned with environmental issues, an area of prime importance in conventional framework of CSR (Khir et al., 2008). In addition, it is widely cited that Islamic financial institutions generally execute a part of their social responsibilities only and are widely accused to have generally ensured their operational status by avoiding impermissible activities, but minimally performing recommended activities (Farook, 2007). It seems that most of Islamic banks focusing more on religious and philanthropic activities and almost ignoring other CSR practices such as concern with social exclusion and human rights, environmental concerns and human resource development.

Looking at the previous studies, they merely discuss the application of CSR in Islamic banks generally and do not really submerge into the actual practice of CSR in Islamic banks from Malaysian perspective and culture. In addition, findings regarding lack of CSR practices in Islamic banks have been published about 12 years ago (see Parvez \& Ahmed, 2004) and the scenario may not be necessarily the same after 12 years of Islamic banks progress and development nowadays. Therefore, the purpose of this research is to explore the CSR application of Islamic banks in Malaysia in order to know how they interpret the notion of CSR and how they execute CSR practices within their institutions at present.

The structure of this paper is as follows: Section 2 reviews of previous literatures. Section 3 describes research methods. Section 4 offers data analysis for the study. The findings are presented in Section 5. Section 6 concludes the paper, highlights the limitations and proposes few suggestions.

\section{LITERATURE REVIEW \\ Concept and Definition}

CSR is a broad topic that covers a multitude of concept and ideas encompassed in as many definitions (see Adnan, 2015), all depending upon the country-of-origin and the originating organization or author (Freeman \& Hasnaoui, 2011). Thus, its conceptualisation is still a debatable issue (Chahal, Mishra, Raina, Soni, \& Matlay, 2015). The definition of CSR has already generated numerous articles and publications from academics, corporations, consultancies, the media, non-governmental organizations and government departments (Crane, 
Matten, \& Spence, 2008). Various definitions have been debated and taken place for more than 50 years now. However, there is no strong consensus on a definition of CSR (Barth \& Wolff, 2009; Jamali, 2008; McWilliams, Siegel, \& Wright, 2006) worldwide probably because the notion of CSR is an elusive one which is abstract and possibly denote a number of different things (Mohammed, 2007).

Maignan and Ralston (2002) define the CSR policy of a firm as the principles and processes present to minimize its negative impacts and maximize its positive impacts on selected stakeholder issues. On the other hand, Davies (2003) simplifies CSR as a set of standards of behaviour to which a corporation subscribes in order to have a positive and productive impact on society. In other words, it is the framework for the role of business in society. CSR Europe (2010) further defines CSR as denoting corporate activities beyond making profits, such as protecting the environment, caring for employees, being ethical in trading and getting involved in the local community. Some of its main issues are promoting human rights, community involvement, human resource management, socially responsible investing and social reporting.

The notion and definition of CSR has evolved impressively throughout history. Carroll (1999) traces the evolution of the CSR structure beginning in the 1950's which marks the modern era of CSR. Definitions further developed during the 1960's and multiplied during the 1970 's. In the 1980's, there were fewer new definitions, more empirical research, and alternative themes began to mature. These alternative themes included corporate social performance (CSP), stakeholder theory, and business ethics theory. In the 1990's, CSR continues to serve as a core construct but transformed into alternative thematic frameworks (Carroll, 1999). However, in the beginning of 21st century, Visser (2011) introduces a comprehensive notion of CSR that stresses not only on the CSR activities but also on CSR end result with new interpretation i.e. CSR stands for "Corporate Sustainability and Responsibility". This development signifies the importance of CSR for both the firms and the public at large.

\section{Corporate Social Responsibility of Islamic Banking}

While Islamic banking industry has progressed to become an increasingly considerable segment within the global financial market, it has been renowned as a viable and competitive form of financial intermediation not only in Muslim countries but also outside the Muslim region and offering an extensive range of financial products and services. The basic differences between Islamic banking and conventional banking, not only in the ways they perform their businesses, but beyond all the values which guide Islamic banking whole operation and outlook (Dusuki, 2008).

These values prevailed within the scope of Shari'ah (Islamic law) are expressed not only in the details of its transactions, but also in the width of its role in society. This requires the internalisation of principles on Islamic financial transactions, in its form, spirit and substance. By doing so, it symbolize the objectives of Shari'ah in promoting both economic and social welfare. In other words, as a Shari'ah-based firm, Islamic banks need to fulfil social obligations that go beyond the conventional capitalist worldview aiming at only maximising profits (Dusuki, 2008). Clearly, Islamic banks operating based on Shari'ah and 
must depart further from conventional banks that are intensely profit motivated. Thus, the concept of brotherhood, social obligations, justice and fairness would be the goals of Islamic banks (Masruki et al., 2010).

Continuation to this debate, many Islamic banking scholars (Ahmad, 2000; Iqbal \& Molyneux, 2005; Lewis \& Algoud, 2001; Warde, 2000) claim that although Islamic banks execute mostly the same functions as conventional banks, they do this in clearly different ways. The most important features of Islamic banking and finance which make it different and unique from its conventional counterpart: firstly, Islamic banking strives for a just, fair and balanced society as envisioned by the Islamic economics. Secondly, Islamic banking is constructed upon the principle of brotherhood and cooperation which stands for a system of equity-sharing, risksharing and stake-taking. Thirdly, as a system grounded on ethical and moral framework of the Shari'ah, Islamic banking is also characterised by ethical norms and social commitments (Dusuki, 2006). Fourthly, Islamic banking is community oriented, entrepreneur-friendly, emphasising productivity and the physical expansion of economic production and services. Finally, Islamic banking operates within limits that ensure stability in the value of money and that reduce destabilizing speculation (Dusuki, 2011).

These characteristics somehow imply the relevance and significance of CSR as a globally accepted practice to Islamic banks. Islamic banking system has an in-built dimension that promotes social responsibility, as it resides within a financial trajectory underpinned by the forces of Shari'ah injunctions. These Shari'ah injunctions intertwine Islamic financial transactions with genuine concern for ethically and socially responsible activities at the same time as prohibiting involvement in illegal activities or those which are detrimental to social and environmental well-being (Dusuki, 2006).

Islamic banks are representative of a new wave of corporations whose social goals are at least as important as making profit (Haniffa \& Hudaib, 2007). Moreover, the notion of social responsibility and justice has been part and parcel of Islamic society for more than 14 centuries and according to Islamic principles, business transactions can never be separated from the moral objectives of the society. Hence, while the virtues of Islam have always advocated social responsibility, the challenge to Islamic banking communities lies in its application. For Islamic banks, good CSR practises should have already been embedded in all aspects of their operations. Indeed, Islamic banking should endeavour to be the epicentre in the financial galaxy of promoting good CSR practices (Asyraf Wajdi \& Dar, 2005).

Nevertheless, there are reasons to believe that the demand for Islamic banks to consider for social objectives may indeed prove to be an illusion. This is because a mass of literature in Islamic banking only focusing on commercial and economic aspects of Islamic banking while social issues with respect to its practices normally occupies back seat in the discussion. This is particularly true when some literature even go further to assert that Islamic banks are no different from other commercial banks except in complying with Shari'ah legal prescriptions pertaining to product offering (El-Gamal, 2006; Ismail, 2002). This view posit that Islamic banks is a typical commercial entity which has a sole responsibility of carrying out business in a manner consistent with Islamic law while social welfare objectives are to be fulfilled by other bodies such as the government (Lewis \& Algoud, 2001). Furthermore, an understanding 
of the concept and importance of CSR is still lacking among the local communities in Malaysia (Amran, Mohamed Zain, Sulaiman, Sarker, \& Say, 2013). Therefore, there is a need for a systematic and in-depth study conducted on Islamic banks to find the truth especially in the current development of Malaysian Islamic banking industry.

\section{METHOD}

\section{Company Selection}

Bank Islam Malaysia Berhad (BIMB) was selected as a subject for this exploratory study based on the reason that BIMB is the first full-fledged local Islamic bank established in Malaysia since 1983. Owing to that vast experience, supposedly, Bank Islam has many CSR activities, practices or programs to share compared to other Islamic banks. This is supported by Azhar, Mohd. Farid Asraf and Fathiyyah (2010) who found that in general, BIMB shows improvement in terms of the amount and the manner of disclosing CSR practices and activities from time to time. Furthermore, all the five BIMB mission statements imply the comprehensiveness of CSR practices in the organization that clearly state as (Bank Islam Malaysia Berhad, 2015):

- To continually develop and innovate universally accepted financial solutions in line with Shari'ah Principles;

- To provide a reasonable and sustainable return to shareholders;

- To provide a conducive working environment and to become an employer of choice for top talents in the market;

- To deliver comprehensive financial solutions of global standards using state-of-the-art technology;

- To be responsible and prudent corporate citizen.

\section{Research Participants}

For this study, three research participants from the BIMB top management level have been interviewed. Face-to-face semi-structured interviews were conducted separately with each participant. They are General Manager of Strategic Relations with 30 years experience working with BIMB, Assistant General Manager of Shari'ah Division with impressive previous and current experience as Shari'ah Audit Manager and Shari'ah Advisor in local and overseas Islamic financial institutions, and lastly Manager of Corporate Responsibility with almost 10 years experience working in corporate world.

The initial identification of the research participants was done by going over the organizational and management hierarchy of BIMB in the website. Contact was established with the shortlisted research participants. Early canvassing of the willingness of participants to be included was through telephone calls and followed by giving brief research introduction and list of interview questions via electronic correspondence (i.e. e-mail). Consequently, the General Manager of Strategic Relations and Assistant General Manager of Shari'ah Division were identified for face-to-face interview. However, the latter gave the contact number of Corporate Responsibility Manager. Later, the appointment dates for interview sessions were set between the main researcher and the research participants. 


\section{Data Collection}

As mentioned in the earlier section, semi-structured face-to-face interview technique was employed for the purpose of this study. The interview with the Assistant General Manager of Shari'ah Division was conducted at Sekolah Menengah Kebangsaan Paka, Paka, Terengganu since BIMB was organizing a CSR programme in that school at that time. Whereas, the interviews with the General Manager of Strategic Relations and Corporate Responsibility Manager were conducted at their offices at Wisma Bank Islam, Jalan Dungun, Bukit Damansara and Menara Bank Islam, Jalan Perak, Kuala Lumpur respectively. The main researcher took about two weeks time to complete all the interview sessions. The total duration of each interview was approximately two hours which amounted to around six hours for total man-hours spent. All research participants were very cooperative in answering researchers' questions and the interviews were audio-recorded.

Face-to-face interview gives advantages to the researchers in getting higher response rate and more accurate data (Zainuddin, 2010). On the other hand, semi-structured interview technique is chosen for this research because it allows the researcher enough flexibility to reword the questions to fit into the interview (Barbour \& Schostak, 2005; Denscombe, 2010). Other advantages of doing semi-structured interview are questions may be reordered during the interview and the interviewer may add or delete probes to interview between subsequent subjects (Berg, 2007). This technique suits the nature of this study, which is exploratory in nature and is a prelude to a larger and more comprehensive investigation.

\section{Research Procedure}

A checklist of CSR items was designed to determine the CSR dimensions. The checklist is based on CSR categorization defined by AAOIFI Standards (2010) and items that are required and recommended by the Standards to disclose in annual reports of Islamic financial institutions, and also based on other established literatures. Some modifications were made to this checklist in order to adapt it to the conditions and characteristics of Islamic banks in the Malaysian context. As a result, seven CSR dimensions were identified and became the focal themes for the interview questions. The seven themes are zakat, charitable activities, employees, customers, business ethics, environment and corporate governance. However, only four themes have been chosen to be analysed in this paper since these themes have been discussed in detail by all three research participants. The four analysed themes are zakat, charitable activities, employees and environment.

\section{DATA ANALYSIS}

As the study proceeded, it became apparent that BIMB has a wide understanding of CSR notion. The following discussion delineates the BIMB commitment towards CSR practices from the data collected. A few quotations that illustrate multiple themes have been chosen to provide richness and nuance in the analysis (Rubin \& Rubin, 2005). 


\section{Zakat}

In the case of business zakat, BIMB plays two roles at the same time, which are as zakat payer and zakat distributor. The approach undertaken by BIMB in paying business zakat is by paying it at bank's level. This is the practice of BIMB since 1983:

"... So, in our case in Malaysia, Fatwa Council has regulated that all Islamic companies need to pay zakat. Therefore, we consider it as a decree or authority asks us to pay zakat. In case of Bank Islam, we pay zakat at bank's level since 1983. At that time, we try to learn from Faisal Islamic Bank in Egypt that pays zakat at bank's level. So we adopted it and we incorporated it in the memorandum of association of the bank ..." (Assistant General Manager of Shari'ah Division, BIMB)

The zakat contribution later will be distributed to all 14 states in Malaysia through their State Religious Councils (SRCs) according to the total deposits of each state. Normally, BIMB will ask three (fuqara', masakin, fi sabilillah ) out of eight zakat asnaf from SRCs to be refunded to the bank for self-disbursement. Then, programmes planned for the refunded zakat disbursement will be tabled to the Bank's Shari'ah Committee for approval. Other than typical charity to poor and destitute Muslims, BIMB also has taken an initiative to build up houses for poor in a state as an annual programme:

"... and we build up houses for hard core poor. We have done a lot. We have given to Kelantan RM1 million, we have given to Terengganu RM1 million..." (General Manager of Strategic Relations, BIMB)

Looking at the approach in disbursing zakat money, all participants portray particularity in using the money for their CSR programmes. Zakat allocation is only used for programmes that fulfil the zakat receiver's entitlement. The budget for any programmes or activities fall beyond the entitlement territory will be taken from the CSR bank's allocation:

“... for example, I bring students to watch movie, poor students, but not all of them are poor. Some of them are from middle class family. So, I cannot use zakat money in this case because in that group of students there are mixed of students who are entitled and not entitled to zakat money. So, I use CSR budget in this case. My budget can be used for non-poor and non-Muslims as well. So, I have to be very careful in using zakat money..." (Corporate Responsibility Manager, BIMB)

\section{Charitable Activities/Community Services}

There are a lot of charitable activities that have been done by BIMB as part of its CSR programmes, for example giving donation to poor families, visiting and giving donation to elderly homes and orphanage, 'Street Feeding Programme' and many other activities:

“... Have you ever heard about 'Street Feeding Programme'? We work out with Reach Out Malaysia (...) Last year we have made simple agreement, not really, but it is like an MOU meaning that starting from January this year every month we join them (...) in terms of medicines we buy panadols, solubles, food, clothes, we give groceries to the poor and destitute..."(Corporate Responsibility Manager, BIMB) 
Generally, the budget for all CSR programmes including for charitable activities are obtained from four resources i.e. zakat, CSR budget, charity fund and Amal Jariah Fund:

“...So the sources of BIMB CSR, number one is the amount allocated by the bank, bank's money (...) number two is zakat, but that is why I said it is difficult. I do not want to say that zakat is CSR but it is one of the sources. Third is from charity fund (...) charity fund is from non-halal income..." (Assistant General Manager, Shari'ah Division, BIMB)

“... Through Bank Islam card every year in Ramadhan from $1^{\text {st }}$ Ramadhan to $30^{\text {th }}$ Ramadhan we have two programmes i.e. 'Amal Jariah Programme' and 'Wakaf al-Qur'an Programme'. This 'Amal Jariah Programme' more towards if you have Bank Islam credit card, every transaction you swipe during Ramadhan (...) $0.3 \%$ from the transaction we will channel it to this fund (...)This money I will use to organize programmes if CSR money is not enough..." (Corporate Responsibility Manager, BIMB)

The budget from all four resources can be used or distributed to all levels of society regardless of religion and financial status except from zakat which is only limited to Muslims who are entitled to be zakat receivers.

\section{Employee Welfare}

BIMB considers its employees are the most valuable assets in gaining and enhancing competitive edges, strengthening operational efficiency, achieving organizational success as well as raising corporate and shareholder value (Bank Islam Malaysia Berhad, 2010). Thus, various measures have been taken in order to safeguard the welfare of the employees. Other than offering attractive remuneration and career advancement, providing diverse facilities at work, providing required training, promoting employees diversity, providing scholarship for study, having social dialogue between management and employee, BIMB also really concern in cultivating Islamic culture in the organization for spiritual development of its staffs:

“... On top of that, for their spiritual development, there is 'Kuliah Zuhur' everyday at Bank Islam funded by the bank (...) On Friday, we have 'Kuliah Muslimat during Jumaat prayer. And every time after Asar prayer, we have 'Kuliah Asar' delivered by Ustaz Faris and friends from Shari'ah Department officers..." (Assistant General Manager, Shari'ah Division, BIMB)

This effort is in parallel with BIMB code of ethics which are Islamically driven. Having Islamic code of ethics can be seen as a complement in inculcating Islamic environment within the Bank:

“... We do confine our code of ethics within Islamic atmosphere. Whatever Islam wants us to do we need to comply with it, because when you talk about Islamic banking, the compliance not just on the banking transaction, but in the entirety. Meaning that, this is including the dress, the wearing, the conduct, etc. That is to conform to the Islamic principle. That's the requirement..." (General Manager of Strategic Relations, BIMB) 
In terms of employees' engagement in CSR activities, BIMB supports its employees in participating in any CSR programmes organized either by the Bank or Bank Islam Staffs Club. Transportation, accommodation, food and beverages are provided to the participants, including Bank Islam t-shirt and cap. All these things are provided in order to encourage and attract employees to partake in CSR programmes:

“... I talk to the branch manager that we will give cap, will get something, we sponsor breakfast and lunch, they (staffs) will like it..." (Corporate Responsibility Manager, BIMB)

\section{Environment}

The application of CSR practices by BIMB does not only focussing on philanthropic activities and developing human capital but also preserving environment programmes. It is found that BIMB has direct and indirect approaches in addressing environmental issues. In terms of direct approach, this can be divided into two programmes i.e. in-door and out-door programmes. For in-door programmes, BIMB addresses in-house environmental concerns by engaging in sustainable processes such as reducing energy, water and paper consumption:

“... For recycling, there are two reasons, no.1 because of cost reduction, no. 2 because of environment thing. For example, we recycle used papers etc. We do have programme in the bank that promotes that thing. Even (...) that thing pops up on our computer screen to remind us. Even there is a rule in the bank, during lunch hour, the staffs go out, they need to switch off (...) the water usage etc..." (Assistant General Manager, Shari'ah Division, BIMB)

On the other hand, for the out-door programmes, BIMB has organized many environmental preservation programmes such as recycling awareness programme with 13 PINTAR $^{3}$ adopted schools nationwide, mangrove planting at Che Mat Zin Island, Klang Selangor, planting gelam trees at Kota Damansara and beach cleaning up at Pantai Teluk Gadung, Dungun, Terengganu. All these programmes were organized with a crystal clear objective which is to save the dying earth:

“... I planted 600 'Api-api'mangrove trees at Che Mat Zin Island, Klang last year. I brought with me 60 staffs. Each of them planted 10 trees. (...) You need to think why we do all these things. We want to save the earth is one thing. And then our next generation, our children. Do they able to see what mangrove tree is like, the forest ..." (Corporate Responsibility Manager, BIMB)

Whereas for indirect approach, although BIMB does not directly involve in green financing and investment, the Bank still consider the environmental impact while approving any financing and investment projects even there is no such policy about that:

“... As a policy, I think we do not have that. But during deliberation in our financing committee, we discuss this matter. For example (...) 'River of Life' project to sustain Klang River and Gombak River. That's funded by Bank Islam. (...) only

\footnotetext{
${ }^{3}$ PINTAR is a school adoption programme powered by Corporate Malaysia, contributing to the Nation Building Agenda.
} 
if you want to say policy, does Bank Islam consider environmental effects when disbursing and financing (...) so far we don't have that policy (...) but we consider something like that..." (Assistant General Manager, Shari'ah Division, BIMB)

\section{FINDINGS}

Based on the interviews conducted, annual report and website disclosure explored together with short observation, obviously BIMB has applied CSR practices in various ways and does not merely focussing on zakat and charitable activities as debated in previous studies (Farook, 2007; Khir et al., 2008). Probably, translator's understanding and motivation on CSR, could be one of the reasons that influence the different outcomes of CSR practices (DitlevSimonsen, 2010) at different Islamic financial institutions. The application of CSR by BIMB are founded on four core pillars namely, workplace, marketplace, community and environment. These four pillars are in parallel with the CSR Framework for Malaysian Public Listed Companies which has been launched by Bursa Malaysia on 5th September 2006 (Yusli, 2007).

It is evident that BIMB has a comprehensive application of CSR. All the four CSR focal areas are clearly spelt out in the Bank website (Bank Islam Malaysia Berhad, 2017) i.e. inspiring the workplace by promoting diversity in the workplace, enriching marketplace by raising public awareness towards Shari'ah-based products and services, elevating communities by uplifting the livelihood and wellbeing of communities and lastly sustaining the environment by improving, protecting and preserving the environment. In fact, sustaining the environment is consistent with the Islamic perspective of CSR where human beings are regarded as 'khalifah' (vicegerent on earth) and among others are required to take care of the natural environment entrusted to them (Darus, Yusoff, \& Mohd Azhari, 2013). The approach adopted represents one of BIMB core brand values which is 'caring' (Bank Islam Malaysia Berhad, 2015). The Bank does not only care about generating profit for the firm, shareholders and depositors, but also care about all the stakeholders surrounding and circling the firm. This is in-line with the findings of Darus et al. (2014) who concluded that the Islamic financial institutions in Malaysia were targeting their CSR activities towards the social development of the community and were mainly concerned about improving the level of education of the community.

At BIMB, CSR goes far beyond donations, sponsorships and charity works. These can be seen from the Bank CSR initiatives and programmes that safeguard all the interest of primary and secondary stakeholders. BIMB does not only fulfil its obligation and responsibility to pay the business zakat on the behalf of shareholders and depositors, but distributes the refunded zakat fund to various mosques, Islamic institutions, religious schools, non-governmental organizations, less fortunate individuals and homes for needy as well. Furthermore, BIMB also allocates special budget for CSR programmes including for community service and environmental projects. This dedicated budget definitely excluding the cost allocated for employees' trainings which is crucial for human capital development. Safeguarding employees' welfare The strong and serious commitment of BIMB towards CSR is evident by having special department that is Corporate Responsibility Department to plan and execute diverse CSR programmes for the Bank. 


\section{CONCLUSION, LIMITATIONS AND RECOMMENDATIONS}

This preliminary study shows that BIMB has applied CSR practices and activities perceptibly in various ways and does not merely focussing on zakat and charitable activities as found in previous studies. In fact, the Bank has systematically planned its diverse CSR initiatives and programmes every year based on four pillars namely workplace, marketplace, community and environment. Surprisingly, besides having typical religious and philanthropic activities, BIMB also shows its concern towards environmental issues by addressing inhouse environmental concerns and organize a significant number of outdoor environmental programmes although the Bank is indirectly related to the environmental issues.

Impressively, albeit a lot of CSR focus is devoted to the community, BIMB does not neglect the welfare of its employees. In line with the mission to be "the employer of choice", effort and commitment to create dynamic and progressive work culture in the Bank has substantially boosted the performance of the employees. Inculcating Islamic environment within the Bank for employees' spiritual development is another noble effort done by the Bank which distinguishes CSR practice between conventional banks and Islamic banks. The results show that BIMB does not only care about those that engage directly in economic transactions with the Bank, but also concern about people, groups or entity that indirectly engage in economic exchange with it. This study also reveals that BIMB executes a few of mandatory (zakat and employee welfare) and recommended (charitable activities and environment) responsibilities in a balanced approach which also in-line with AAOIFI (2010) standards.

However, some limitations in this study need to be acknowledged. Firstly, these preliminary findings cannot be generalized to all Islamic banks in Malaysia since it only focuses on one Islamic bank. The findings would be more applicable if more Islamic banks are included in the sample. Secondly, CSR is an extensive field that cannot be explored thoroughly based on data from three respondents and within total six hours interview. Consequently, the exclusion of customers, business ethics and corporate governance and may be few other CSR themes from the study analysis are due to the inability to get in-depth data and not because of the themes are less important. As such, more respondents and time are needed.

In future research, a comparative study between full-fledged Islamic banks and Islamic subsidiaries or between local Islamic banks and foreign Islamic banks can be conducted. This would reveal whether there are any internal and external factors that influence the differences and similarities of CSR initiatives between them. Moreover, research on the impacts of CSR initiatives towards financial performance, employee performance, bank image, product innovation, customer satisfaction, customer loyalty, investor interest, etc. can be further explored in order to see the extent of CSR benefits to the Islamic banks. 


\section{REFERENCES}

AAOIFI Standards. (2010). Accounting, Auditing and Governance Standards for Islamic Financial Institutions Governance Standard for Islamic Financial Institutions No. 7.

Adnan, A. A. (2015). The Missing Dimension of Corporate Social Responsibility (CSR) Measurement in Malaysian Islamic Banks. British Journal of Economics, Finance and Management Sciences, 10(1), 16-28.

Ahmad, A. (2000). Economic development in Islamic perspective revisited. Review of Islamic Economics, 9, 83-102.

Amran, A., Mohamed Zain, M., Sulaiman, M., Sarker, T., \& Say, K. O. (2013). Empowering Society for Better Corporate Social Responsibility (CSR): The Case of Malaysia. Kajian Malaysia, 31(1), 57-78.

Bank Islam Malaysia Berhad. (2010). 2010 Annual Report. Kuala Lumpur: Bank Islam Malaysia Berhad.

Bank Islam Malaysia Berhad. (2015). 2015 Annual Report. Kuala Lumpur: Bank Islam Malaysia Berhad.

Bank Islam Malaysia Berhad. (2017). Corporate Responsibility. Retrieved from http://www. bankislam.com.my/home/corporate-responsibility/about-cr/

Barbour, R. S., \& Schostak, J. (2005). Interviewing and Focus Groups. In B. Somekh \& C. Lewin (Eds.), Research Methods in the Social Sciences (pp. 41-48). London: SAGE Publications.

Barth, R., \& Wolff, F. (2009). Corporate social responsibility and sustainability impact: Opening up the arena. In R. Barth \& F. Wolff (Eds.), Corporate social responsiblity in Europe Rhetoric and realities (pp. 3-25). Cheltenham: Edward Elgar Publishing.

Berg, B. L. (2007). Qualitative Research Methods for the Social Sciences (6th ed.). Boston: Pearson International Edition.

Carroll, A. B. (1999). Corporate social responsibility: Evolution of a definitional construct. Business and Society, 38(3), 268-295.

Chahal, H., Mishra, S., Raina, S., Soni, T., \& Matlay, H. (2015). A Comprehensive Model of Business Social Responsibility (BSR) for Small Scale Enterprises. Journal of Small Business and Enterprise Development, 22(2), 1-35.

Crane, A., Matten, D., \& Spence, L. J. (2008). Corporate social responsibility: In a global context. In A. Crane, D. Matten, \& L. J. Spence (Eds.), Corporate social responsibility: readings and cases in a global context (pp. 3-20). New York: Routledge.

CSR Europe. (2010). European postal services and social responsibilities. Retrieved from Brussels: http://www.corporate-citizenship.com/wp-content/uploads/2009/06/postoffices.pdf 
Darus, F., Amran, A., Nejati, M., \& Yusoff, H. (2014). Corporate social responsibility towards the community: evidence from Islamic financial institutions in Malaysia. International Journal of Green Economics, 8(3-4), 273-287.

Darus, F., Yusoff, H., \& Mohd Azhari, N. K. (2013). Environmental Disclosure of Islamic Financial Institutions (IFIs): Preliminary Evidence from Malaysia. Journal of Energy Technologies and Policy, 3(11), 433-439.

Darus, F., Yusoff, H., Zain, M. M., \& Amran, A. (2016). CSR TO i-CSR: Enhancing Corporate Social Accountability Practices of Islamic Organisations. Middle-East Journal of Scientific Research, 24(4), 1094-1103.

Davies, R. (2003). The business community: Social responsibility and corporate values. In J. H. Dunning (Ed.), Making globalization good: The moral challenges of global capitalism (pp. 301-319). Oxford: Oxford University Press.

Denscombe, M. (2010). The Good Research Guide for Small-Scale Social Research Projects (4th ed.). Maidenhead, England: McGraw Hill.

Ditlev-Simonsen, C. D. (2010). From Corporate Social Responsibility Awareness to Action? Social Responsibility Journal, 6(3), 452-468.

Dusuki, A. W. (2006, 26th - 28th June 2006). Stakeholders' expectation towards corporate social responsibility of Islamic banks. Paper presented at the International Accounting Conference III (INTAC 3), International Islamic University Malaysia, Kuala Lumpur.

Dusuki, A. W. (2008). Understanding the Objectives of Islamic Banking: A Survey of Stakeholders' Perspectives. International Journal of Islamic and Middle Eastern Finance and Management, 1(2), 132-148.

Dusuki, A. W. (2011). Ethical and Social Responsibility Models for Islamic Finance. ISRA Research Paper. International Shari'ah Research Academy (ISRA).

El-Gamal, M. A. (2006). Islamic Finance: Law, Economics, and Practice. Cambridge: Cambridge University Press.

Farook, S. (2007). On Corporate Social Responsibility of Islamic Financial Institutions. Islamic Economic Studies, 15(1), 31-46.

Freeman, I., \& Hasnaoui, A. (2011). The meaning of corporate social responsibility: The vision of four nations. Journal of business Ethics, 100(3), 419-443.

Haniffa, R., \& Hudaib, M. (2007). Exploring the Ethical Identity of Islamic Banks via Communication in Annual Reports. Journal of business Ethics, 76(1), 97-116.

Hassan, A., \& Harahap, S. S. (2010). Exploring Corporate Social Responsibility Disclosure: The Case of Islamic Banks. International Journal and Middle Eastern Finance and Management, 3(3), 203-227.

Iqbal, M., \& Molyneux, P. (2005). Thirty years of Islamic banking: History, performance and prospects. New York: Palgrave Macmillan. 
Islamic banking.com. (2011). Corporate social responsibilities. Retrieved from http://www. islamic-banking.com/csr.aspx

Ismail, A. H. (2002). The deferred contracts of exchange: Al-Quran in contrast with the Islamic economists theory on banking and finance. Kuala Lumpur: Institute of Islamic Understanding Malaysia (IKIM).

Jamali, D. (2008). A Stakeholder Approach to Corporate Social Responsibility: A Fresh Perspective into Theory and Practice. Journal of business Ethics, 82(1), 213-231.

Jamali, D., \& Karam, C. (2016). Corporate Social Responsibility in Developing Countries as an Emerging Field of Study. International Journal of Management Reviews. doi:10.1111/ ijmr.12112

Khir, K., Gupta, L., \& Shanmugam, B. (2008). Islamic Banking: A Practical Perspective. Petaling Jaya: Pearson Longman.

Lewis, M. K., \& Algoud, L. M. (2001). Islamic Banking. Cheltenham, UK and Northampton, USA: Edward Elgar.

Maignan, I., \& Ralston, D. A. (2002). Corporate Social Responsibility in Europe and the US: Insights from Business' Self-presentation. Journal of International Business Studies, $33(3), 497-514$.

Masruki, R., Ibrahim, N., \& Azizan, N. A. (2010, 13 - 15 December 2010). Incorporating Corporate Social Responsibility (CSR) into Sustainable Financial Performance of Islamic Banks in Malaysia. Paper presented at the 2nd Langkawi Islamic Finance and Economics International Conference (LIFE 2010), Langkawi, Malaysia.

McWilliams, A., Siegel, D. S., \& Wright, P. M. (2006). Corporate social responsibility: Strategic implications. Journal of Management Studies, 43(1), 1-18.

Mohammed, J. A. (2007). Corporate Social Responsibility in Islam (PhD), Auckland University of Technology, Auckland.

Parvez, Z., \& Ahmed, P. (2004). An Islamic Perspective on the Lack of Social Responsibility in Business Organizations. Working Paper Series 2004. Working Paper Series 2004. Wolverhampton University Business School. University of Wolverhampton, UK.

Rahman, A. A., Hashim, M. F. A. M., \& Bakar, F. A. (2010). Corporate Social Reporting: A Preliminary Study of Bank Islam Malaysia Berhad (BIMB). Issues in Social \& Environmental Accounting, 4(1), 18-39.

Rubin, H. J., \& Rubin, I. S. (2005). Qualitative interviewing: The art of hearing data (2nd ed.). Thousand Oaks, California: Sage Publications, Inc.

Visser, W. (2011). The ages and stages of CSR: Towards the future with CSR 2.0. CSR International Paper Series(3).

Warde, I. (2000). Islamic Finance in the Global Economy. Edinburgh: Edinburgh University Press. 
Wilson, R. (2001). Business ethics: Western and Islamic perspectives. In K. Ahmad \& A. M. Sadeq (Eds.), Ethics in Management and Business: Islamic and Mainstream Perspectives. London: ASEAN Academic Press.

Yusli, M. Y. (2007). Introduction. In M. A. Mohd Nizam, M. I. Mohd Rezaidi, M. Y. Noor Yuslinda, \& Y. Mohd Yany (Eds.), Corporate social responsibility: Our first look. Kuala Lumpur: Malaysian Institute of Integrity.

Zainuddin, A. (2010). Research methodology for business \& social science. Shah Alam: UPENA Universiti Teknologi MARA.

\section{ACKNOWLEDGEMENT}

The authors would like to express their gratitude to the Ministry of Higher Education, Malaysia and Universiti Teknologi MARA, Malaysia for funding and facilitating this research project. 